\title{
Kompakt Kent Ölçütlerinden Biri Olan Yoğunluk Tespiti ve Değerlendirmesi: Türkiye Kentleri (II Merkezleri) Örneği
}

\author{
Determining and Assessing the Urban Density which is One \\ of the Compact City Parameters: Case of Turkey Cities
}

\author{
(D) Mediha Burcu Sılaydın Aydın, Emine Duygu Kahraman \\ Dokuz Eylül Üniversitesi Mimarlık Fakültesi, Şehir ve Bölge Planlama Bölümü, İzmir
}

\section{ÖZ}

Kompakt kent modeli, sürdürülebilir kentsel gelişim arayışlarında sıkça gündeme getirilen yaklaşımlardan biridir. Yaklaşımın temel amacı, yaygın gelişim nedeniyle yaşanan ekonomik, sosyal ve çevresel sorunların önüne geçmektir. Kompakt kent modelinin fonksiyonlar arası mesafelerin kısaldığı yüksek yoğunluklu yapılaşma yaklaşımı, özellikle iklim değişikliğini hafifletme hedefinde ilerleyen sera gazı azaltım politikaları bağlamında önemli bir yer tutmaktadır. Bu makalenin amacı, Türkiye kentlerinin (8I il merkezi) yerleşik alan sınırları temel alınarak, en önemli kompakt kent ölçütlerinden biri olan kentsel brüt nüfus yoğunluklarını hesaplamaktır. Bu doğrultuda öncelikle ulusal literatüre kentsel brüt nüfus yoğunlukları ve yerleşik alan büyüklüklerine ilişkin veri kazandırılması hedeflenmiştir. Makalede ayrıca kentlerin büyükşehir statüsünde olup olmamalarına göre kategorize edildikten sonra nüfus yoğunlukları, yerleşik alan büyüklükleri ve nüfusları arasındaki ilişki yönü ve şiddetine dair analizler yapılmış ve böylelikle kentlerin kompaktlık açısından değerlendirilebilmesine yönelik kullanılması gereken ölçütlerden biri olan yoğunluğa ilişkin analizler gerçekleştirilmiştir. Elde edilen sonuçlar dünya kentleri ile karşılaştırmalı değerlendirildiğinde, ülkemizdeki kentlerin yüksek brüt nüfus yoğunluklarına sahip olduğunu ve sadece nüfus yoğunluğu kriteri gözetildiğinde, genel olarak, kompaktlık kriterlerinden birini sağlayan bir profil çizdiğini göstermektedir.

Anahtar sözcükler: Brüt nüfus yoğunluğu; kompakt kent; merkez kentler, Türkiye.

\begin{abstract}
Compact urban settlement is one of the approaches that has been often discussed in the search for sustainable urban development. The main aim of the approach is to prevent economic, social, and environmental problems caused by urban sprawl. The compact urban model's high-density build-up approach plays an important role in the context of greenhouse gas reduction policy that is particularly targeted at mitigating climate change by shortening the distances between functions. The purpose of the present study, on the basis of built-up area boundaries of the cities in Turkey ( $8 \mathrm{I}$ cities), was to calculate the urban gross population density which is one of the most important compact city parameters. In this context, first, the present study aimed to provide data to the national literature on urban gross population densities and built-up area sizes. Cities were also categorized according to whether they are in metropolitan municipality status or not, and the strength and direction were calculated with the correlation analysis between population, population density, and built-up area size, and thus population density, which should be used for the evaluation of cities with respect to compactness, analysis was conducted. The cities in our country have high gross population densities compared with world cities, and generally, considering only the population density parameter, they show a profile that provides one of the criteria for compactness.
\end{abstract}

Keywords: Gross population density; compact city; central cities; Turkey. 


\section{Giriş}

Kompakt kent, sürdürülebilir kentsel gelişim arayışlarında sıkça gündeme getirilen yaklaşımlardan biridir. Yaklaşımın amacı, kentsel saçaklanma nedeniyle yaşanan ekonomik, sosyal ve çevresel sorunların önüne geçmektir. Burgess (2000) tarafından kompakt kent, kentsel fonksiyonların yoğunlaşmasından kaynaklanan çevresel, sosyal ve küresel sürdürülebilirlik arayışında, yapı ve nüfus yoğunluklarını artırmak, kentsel ekonomik, sosyal ve kültürel aktiviteleri yoğunlaştırmak ve kentsel büyüklük, biçim, yapı ve yerleşim sistemlerini idare etmek şeklinde tanımlamıştır. Kentsel yoğunlaşmanın kent çevresindeki doğal alanları koruma adına önem taşıması da yaklaşımın sürdürülebilir yapılaşmanın önemli araçlarından biri olarak ele alınmasına neden olmuştur (Aydın, 20I5). Ayrıca kompakt gelişim, fonksiyonlar arası mesafeleri kısaltarak ulaşımdan kaynaklanan sera gazı emisyonlarını azaltacağı için özellikle enerji tasarrufları ve iklim değişikliğini hafifletme politikaları bağlamında önemli bir yer tutmaktadır. Öte yandan literatürde kompakt kent yaklaşımının avantajlı yanlarının yanı sıra çevresel, ekonomik, sosyal ve hatta psikolojik açıdan dezavantajlı yanları da ortaya konmakta (örn. Lin ve Yang, 2006; Tosun, 2013) ve sürdürülebilir yerleşimler arayışında genel geçer bir yaklaşım olamayacağı savunulmaktadır (van der Walls, 2000; Neuman, 2005). Özellikle kentleşme pratiklerinin gelişmiş ve gelişmekte olan ülkeler arasında bir takım farklılıklar içermesi, kompakt kentin gelişmekte olan ülkeler açısından sürdürülebilirliğe hizmet edecek bir yaklaşım olup olmadığının sorgulanmasına neden olmaktadır (Richardson ve diğ., 2000; Carmona, 2000). Burgess (2000), gelişmekte olan ülkelerin çoğunun 20. yy'ın sonlarında hala demografik ve kentsel dönüşüm süreçlerinin başlangıç veya orta aşamasında olduklarını vurgulamış ve kompakt kent politikalarının gelişmiş veya gelişmekte olan ülkeler arasındaki kentleşme ve kentsel büyüme oranlarındaki farklılıkları göz önüne almak zorunda olduğunu belirtmiştir. Gelişmiş ve gelişmekte olan ülkeler arasında gözetilmesi gereken farklılıklardan birini nüfus yoğunlukları oluşturmaktadır. Gelişmekte olan ülkelerin kentlerindeki yoğunluklar, gelişmiş ülkelerinkinden çok daha fazladır (Richardson ve diğ., 2000). Örneğin Avrupa kentlerinde merkezler ortalama 50-55 kişi/hektar iken; bu değer Asya kentlerinde 150 kişi/hektar değerine ulaşmaktadır (Kenworty, 2006). Yüksek yoğunluklu gelişim kompakt kent modelinin temel özelliklerinden birini oluşturmaktadir (Gordon ve Richardson, 1997; Burton, 2000; Neuman, 2005; Tsai, 2005; Jabareen, 2006). Bu nedenle yoğunluk, bir kentsel yerleşmenin kompaktlık veya saçaklanma durumunun ölçülmesi için kullanılan temel kriterler arasında yer almakta (Galster ve diğ., 200I; Burton, 2002; Lee ve diğ., 2015); dolayısıyla yüksek yoğunluklu gelişimin sorgulanması, modelin belirli bir ülke için uygunluğunun sınanmasında önemli hale gelmektedir.
Bu makalenin amacı, Türkiye kentlerinin (8I il merkezi) yerleşik alan sınırları temel alınarak, en önemli kompakt kent ölçütlerinden biri olan kentsel nüfus yoğunluklarını hesaplamaktır. Bu doğrultuda öncelikle ulusal literatüre kentsel nüfus yoğunlukları ve yerleşik alan büyüklüklerine ilişkin veri kazandırılması hedeflenmiştir. Makalede ayrıca kentlerin büyükşehir statüsünde olup olmamalarına göre kategorize edildikten sonra nüfus yoğunlukları, yerleşik alan büyüklükleri ve nüfusları arasındaki ilişki yönü ve şiddetine dair analizler yapılmış ve böylelikle kentlerin kompaktlık açısından değerlendirilebilmesine yönelik kullanılması gereken ölçütlerden biri olan yoğunluğa ilişkin analizler gerçekleştirilmiştir.

\section{Veri ve Yöntem}

Kentsel nüfus yoğunlukları, Türkiye'deki 8I il merkezi için hesaplanmıştır. Kentlerin nüfus yoğunluğu, kent nüfusunun, yerleşik alan büyüklüğüne bölünmesi işlemi ile elde edilmiştir.

Kent nüfusları, TÜiK Adrese Dayalı Nüfus Kayıt Sistemi'ne ait 2015 yılı verilerinden elde edilmiştir (Tablo I). Bu noktada nüfus verileri açısından büyükşehir statüsünde olan iller açısından farklı bir durum ortaya çıkmıştır. Büyükşehir statüsünde olmayan illerin merkez nüfusları merkez ilçe verisi halinde TÜiK Adrese Dayalı Nüfus Kayıt Sistemi'nden doğrudan elde edilebilmiştir. Ancak büyükşehir statüsünde olan iller için böyle bir merkez ilçe nüfus bilgisi bulunmamakta; ilçe verisi bilgileri de kentin (il merkezinin) nüfus büyüklüğünü doğrudan vermemektedir. Örneğin büyükşehir belediyesi statüsünde olan İzmir'in toplam 30 ilçesi vardır. Bu ilçelerden II tanesi il merkezinin kentsel yerleşik dokusunu oluşturmaktadır ve bu II ilçenin nüfusları toplamı kent nüfusunu vermektedir. Bu nedenle büyükşehir statüsündeki 30 il için hesaplamalar yapılırken, kentlerin yerleşik dokusunu oluşturan ilçeler saptanmış ve bu ilçelere ait nüfus verileri kullanılmıştır.

Kentsel yerleşik alan büyüklüğü ölçümleri için Google Earth Pro (20I5) programından yararlanılmıştır. Yerleşik alan büyüklükleri, Google Earth Pro programının çokgen ölçümü işlemiyle (Şekil la) hesaplanmıştır. Alan ölçümleri, 8I il merkezinin tamamında ve $600 \mathrm{~m}$.-750 m. arasında değişen göz hizası duyarlılığında yapılmıştır (Şekil Ib). Çokgen ölçümü yapabilmek için kentsel yerleşik alan sınırı çizilirken (Şekil 2) kent çeperinde yer alan en son konut birimleri sınır olarak alınmıştır (Şekil 3).

Yerleşik alan sınırı çiziminde kentin çeperindeki son konut birimi esas alındığı için, kente yakın/bitişik konumda bulunmakla birlikte son konut birimlerinin oluşturduğu sınırın dışında kalan konut dışı kullanım alanları (organize sanayi bölgesi, havaalanı, rekreasyon alanı vb.), yerleşik alan sınırı 
Tablo I. Kent (il merkezleri) nüfusları (2015)

\begin{tabular}{|c|c|c|c|c|c|}
\hline İl adı & Nüfus & İl adı & Nüfus & İl adı & Nüfus \\
\hline Adana & 1717473 & Giresun & 107075 & Samsun & 637907 \\
\hline Adiyaman & 238711 & Gümüşhane & 41604 & Siirt & $|45| 44$ \\
\hline Afyon & 217805 & Hakkari & 57961 & Sinop & 40667 \\
\hline Ağrı & II 6359 & Hatay & 360652 & Sivas & 329082 \\
\hline Amasya & 101813 & Isparta & 214096 & Tekirdağ & 187727 \\
\hline Ankara & 4573460 & Mersin & 970626 & Tokat & 142724 \\
\hline Antalya & II 97948 & İstanbul & 13865524 & Trabzon & 320225 \\
\hline Artvin & 25838 & İzmir & $289 \mid 492$ & Tunceli & 34461 \\
\hline Aydın & 277466 & Kars & 81742 & Şanlıurfa & 865769 \\
\hline Balıkesir & 347072 & Kastamonu & 110908 & Uşak & 201634 \\
\hline Bilecik & 59163 & Kayseri & 1074325 & Van & 554002 \\
\hline Bingöl & 108267 & Kırklareli & 73517 & Yozgat & 81920 \\
\hline Bitlis & 48948 & Kırşehir & 125807 & Zonguldak & 108074 \\
\hline Bolu & 153783 & Kocaeli & 979795 & Aksaray & 202336 \\
\hline Burdur & 78331 & Konya & 1250482 & Bayburt & 37946 \\
\hline Bursa & 1947266 & Kütahya & 236096 & Karaman & 152256 \\
\hline Çanakkale & 122613 & Malatya & 595935 & Kırıkkale & 190486 \\
\hline Çankırı & 79091 & Manisa & 380368 & Batman & 392738 \\
\hline Çorum & 250464 & K.maraş & 603020 & Şırnak & 63367 \\
\hline Denizli & $6 I 134 \mid$ & Mardin & 156660 & Bartın & 66091 \\
\hline Diyarbakır & 1008848 & Muğla & 105860 & Ardahan & 19777 \\
\hline Edirne & 158369 & Muş & 91126 & lğdır & 88476 \\
\hline Elazığ & 367156 & Nevşehir & 98713 & Yalova & 112183 \\
\hline Erzincan & 95596 & Niğde & 132155 & Karabük & 117557 \\
\hline Erzurum & 358820 & Ordu & 202310 & Kilis & 93266 \\
\hline Eskişehir & 717076 & Rize & 111212 & Osmaniye & 223987 \\
\hline Gaziantep & I597324 & Sakarya & 511102 & Düzce & 153504 \\
\hline
\end{tabular}

Kaynak: TUiK Adrese Dayalı Nüfus Kayıt Sistemi.

çiziminin ve dolayısıyla alan hesaplamasının dışında tutulmuştur (Şekil 4). Bununla birlikte kentsel yerleşik alan sınırı içerisinde kalan her türlü kullanım (yollar, dereler, kentsel boşluklar, ağaçılık alanlar vb.) yerleşik alan büyüklüğüne dahil edilmiştir (Şekil 5). Dolayısıyla hesaplanan değerler, kentlere ait brüt yoğunlukları ifade etmektedir.

Yerleşik alan sınırının çizilmesinde farklı mekansal gelişim desenleri sergileyen kentlere ilişkin açılamaya da gerek bulunmaktadır. Şekil 2'de Amasya ile örneği verilen kentlerde, ölçümleri kolaylaştıran nitelikte sürekli bir kentsel form gözlenmektedir. Bununla birlikte bazı kentlerde sıçramalı veya dağııık gelişim özellikleri görülmektedir. Çizim sırasında, konutların süreklilik göstermesi kriterine dikkat edilmiştir. Öte yandan kentsel yerleşik alan büyüklüğü öl- çülürken, sıçramalı gelişim gösteren kentlerde, süreklilik olmasa da nüfusun bir bölümünü barındırdığı için kentten mekansal olarak kopuk bu bölgeler de hesaplamaya dahil edilmiştir (Şekil 6).

Karadeniz kentleri gibi dağınık yerleşim özelliği sergileyen kentlerde ise süreklilik göstermeyen dağınık konut yapıları, kentsel yerleşik alan büyüklüğü hesaplamasının dışında tutulmuştur (Şekil 7).

\section{Sonuçlar}

Kentlerin yerleşik alan sınırı çizimlerinin tamamlanarak büyüklüklerinin ölçülmesi işi yaklaşık bir buçuk yıl sürmüştür. Çizimlere 2015 yılında başlandığı ve Google Earth Pro prog- 


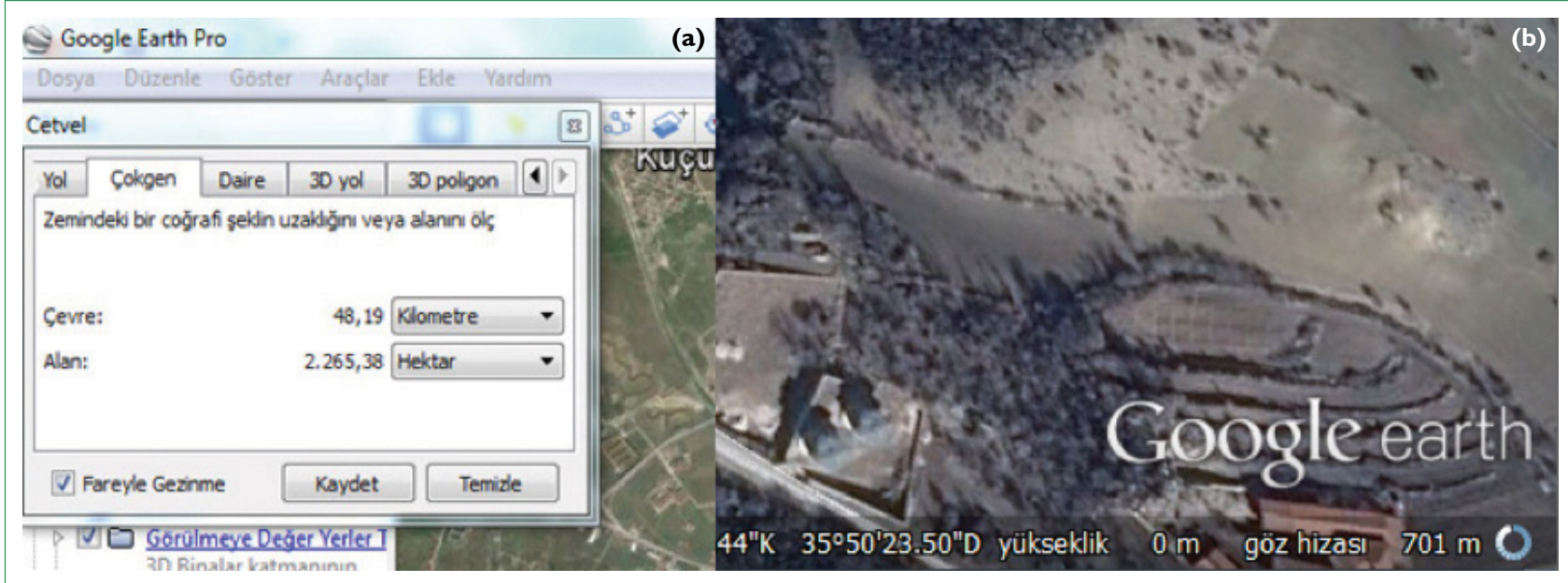

Şekil I. (a) Google Earth Pro - çokgen ölçümü, (b) Google Earth Pro - göz hizası.

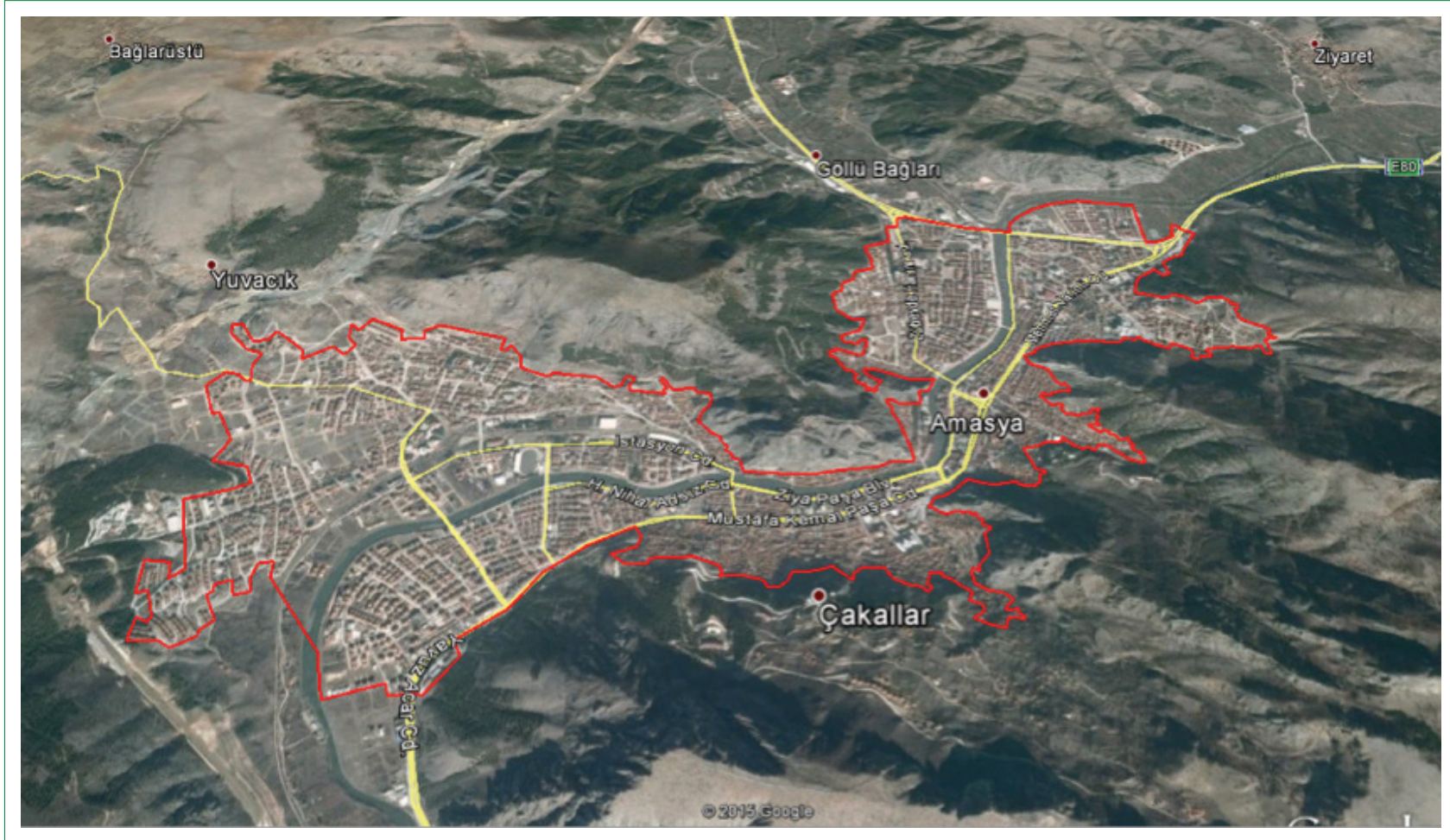

Şekil 2. Merkez kent yerleşik alan sınırının çizimi (Amasya örneği) (Kaynak: Google Earth Pro programından yararlanarak yazarlar tarafından çizilmiştir).

ramının 2015 yılına ait görüntülerinden' yararlanıldığı için, nüfus yoğunluklarının hesaplanmasında da 2015 yılı nüfus verileri esas alınmıştır (Tablo I). Kısaca araştırmanın sonuçları 20 I5 yılına ait hesaplamaları içermektedir.
Türkiye'deki 8I il merkezinin kentsel yerleşik alan büyüklükleri 193 ha. (Artvin) ile 87.145 ha. (İstanbul) arasında değişim göstermektedir (Tablo 2). Türkiye'nin il merkezlerinin toplam yerleşik alan büyüklüğü 4 I 5.775 hektardır. Kentlerin

Google Earth Pro programında, görüntülerinde yıllar farklılık gösterebilmektedir. Bu makalede ölçüm yapılan Google Earth Pro 2015 yılı verisinde kentlerin büyük çoğunluğuna (\%70 oranında) ait 2015 yılı görüntüsü elde edilmiştir. Ancak kentlerin \%30'una ait 2013 ve 2014 yılı görüntüleri olduğu görülmüş ve bu görüntüler üzerinden ölçüm yapılmıştır. Daha sonra 2016 ve 2017 yıllarına gelindiğinde, 2013 ve 2014 yılına ait ölçümleri yapılan kentlerin görüntülerinin güncellenip güncellenmediği kontrol edilmiştir. Bu noktada sözünü ettiğimiz \%30 oranında kentin (24 kent) 2015 yılına ait uydu görüntüsü olmadığı görülmüştür. Bu durumda, bu kentlerin 2016 görüntüleri ile 2013/2014 görüntüleri karşılaştırılmış ve kentsel yerleşik alan büyüklüğünde meydana gelen değişimler ölçülmüştür. Yapılan karşılaştırma sonucunda, 4 kentte hiç değişim olmadığı tespit edilmiştir. Geri kalan 20 kentte meydana gelen değişikliklerin ise nüfus yoğunluklarına etkisinin göz ardı edilebilecek kadar küçük (I kişi/ha değerinin altında kalmaktadır) olduğu hesaplanmıştır. Google Earth Pro programında görüntülerdeki yıl farklılıkları belli bir yıla özgü olmayan, süreklilik arz eden bir durum olduğundan; farkl verilerin karşılaştırılabilmesi için yıl birlikteliği önemli olduğundan; kentlerin çoğunluğuna ait 2015 yılı görüntüsü bulunduğundan ve 2016 yılı ile karşılaştırmalı değerlendirme sonucunda meydana gelen değişimlerin gözardı edilebilecek kadar küçük bir değere sahip olduğu saptandığından, 2015 yılı Google Earth Pro verileri verileri esas alınmıştır. 


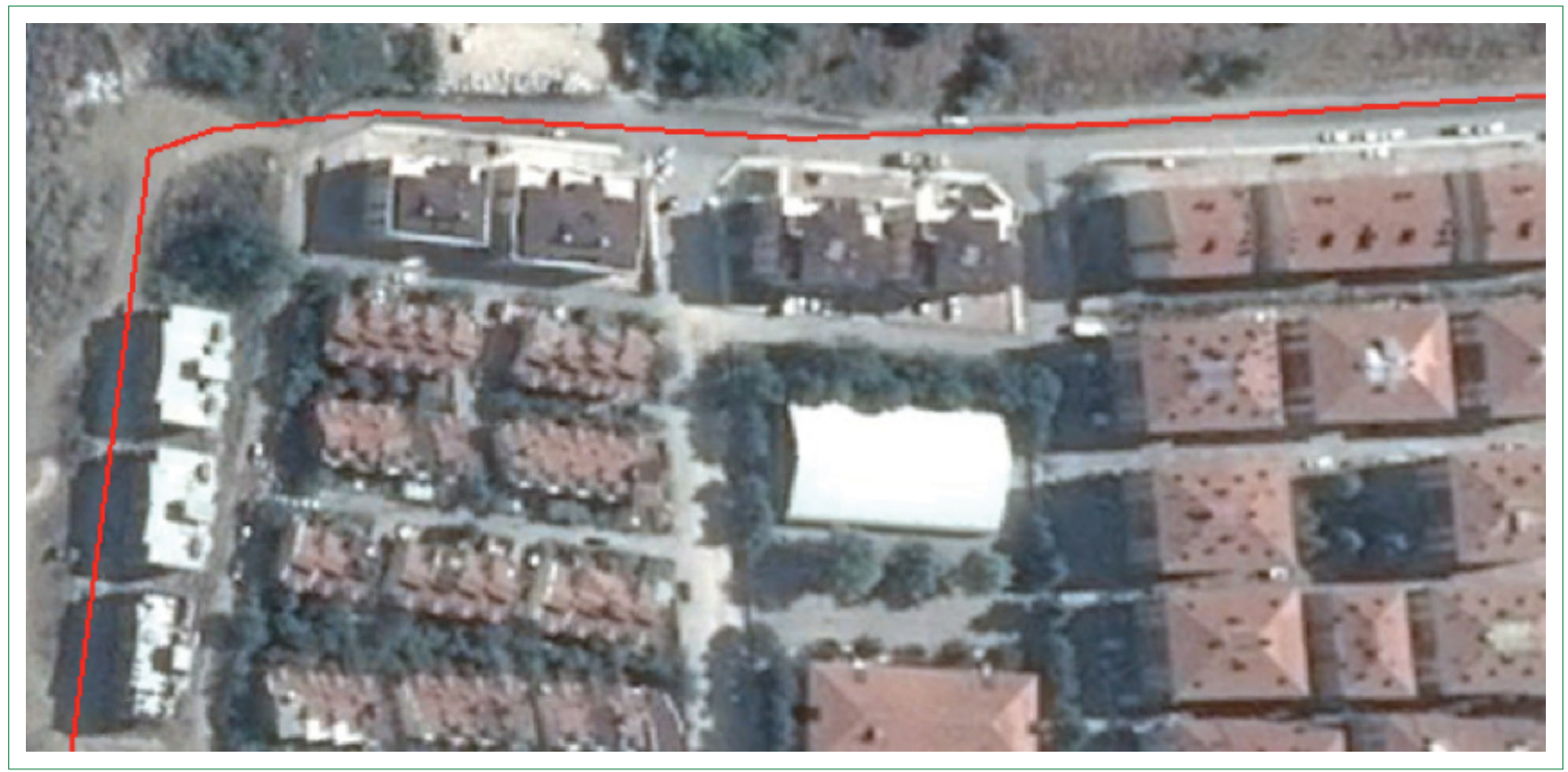

Şekil 3. Yerleşik alan sınıı çizimi - yakın görünüm (Kaynak: Google Earth Pro programından yararlanarak yazarlar tarafından çizilmiştir).

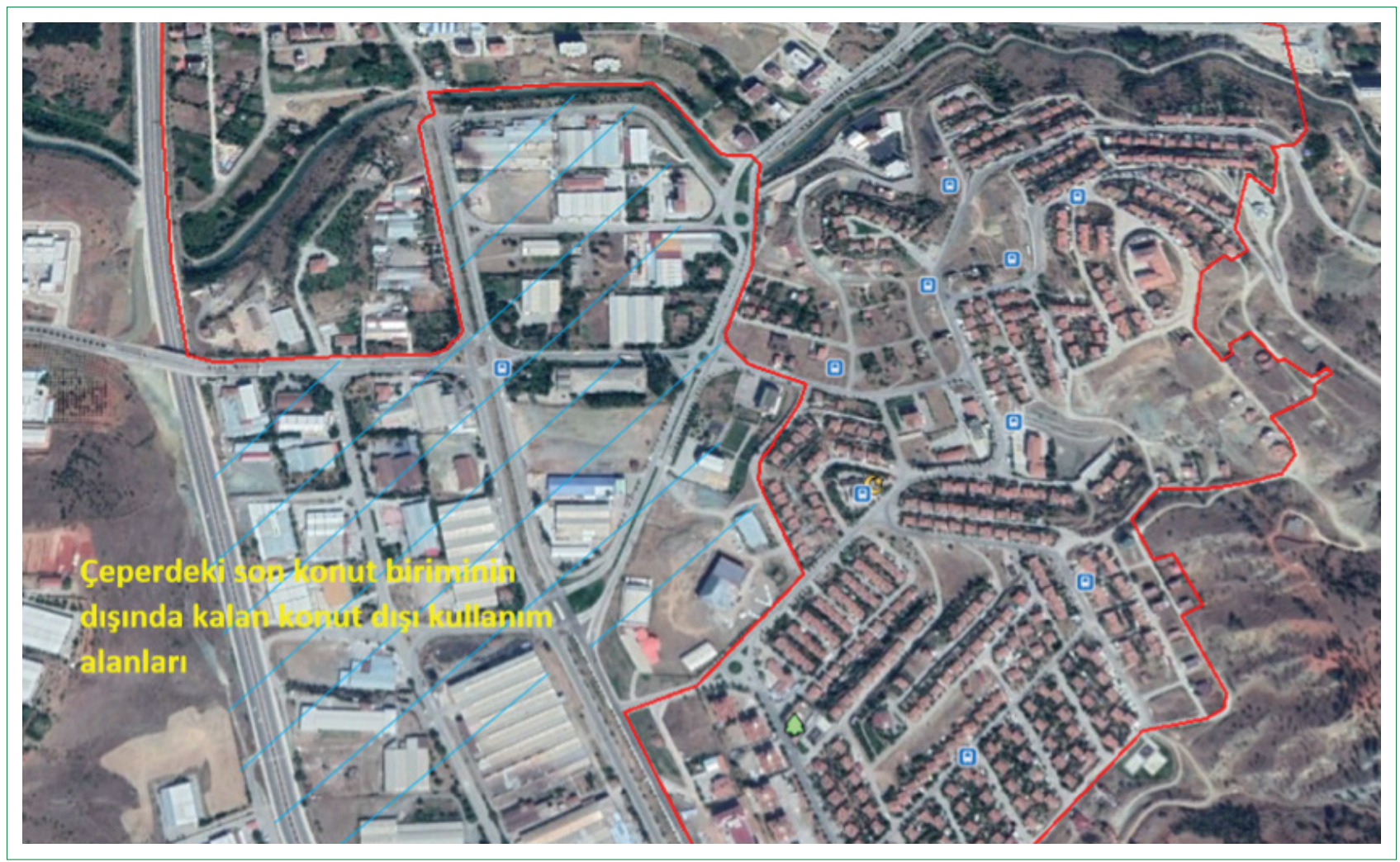

Şekil 4. Hesaplamaya alınmayan konut dışı kentsel kullanım örneği (Tokat merkez kentin doğusundan bir örnek) (Kaynak: Google Earth Pro programından yararlanarak yazarlar tarafından çizilmiştir).

nüfus yoğunlukları incelendiğinde, 27,77 kişi/hektar (Erzincan) ile 194,66 kişi/hektar (Manisa) arasında değişim gösterdiği görülmektedir (Tablo 3). Türkiye'de kentlerin ortalama yoğunluğu ise $\mathbf{1 0 0 , 3 7 ~ k i s ̧ i / h e k t a r ~ o l a r a k ~ h e s a p l a n m ı s ̧ t ı r . ~}$
Türkiye'deki 30 büyükşehir belediyesi arasında en yüksek yoğunluğa sahip kent 194,66 kişi/ha değeri ile Manisa iken; en düşük yoğunluğa sahip kent 5I,67 kişi/ha değeri ile Van olarak ölçülmüştür. Ülke genelinde büyükşehir belediyesi statüsüne 


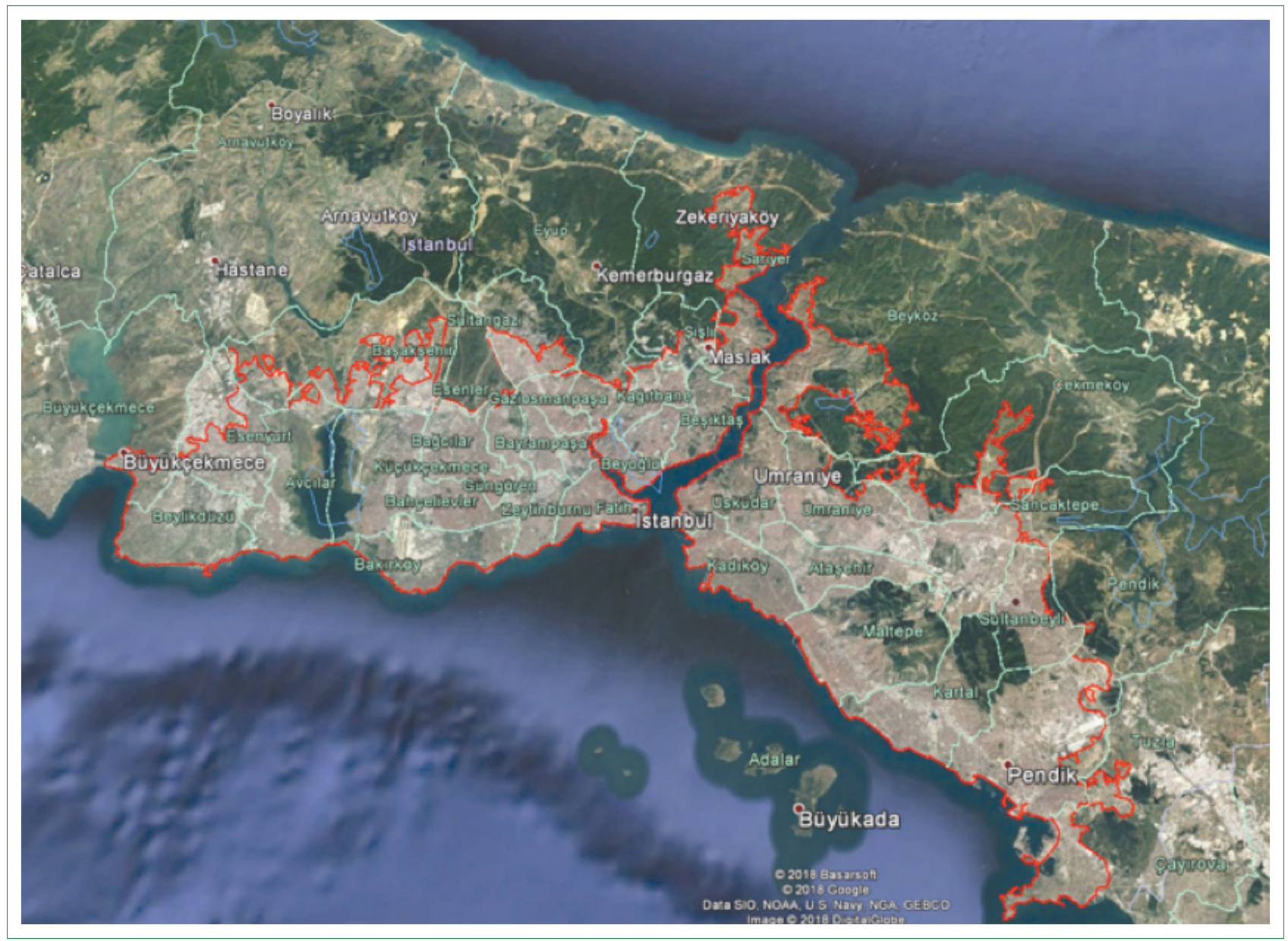

Şekil 5. Yerleşik alan sınıları içerisinde kalan boşluklu alan kullanımlarının yerleşik alan büyüklüğüne dahil edilmesi (İstanbul örneği) (Kaynak: Google Earth Pro programından yararlanarak yazarlar tarafından çizilmiştir).

sahip kentlerin ortalama nüfus yoğunlukları 130,10 kişi/ha olarak hesaplanmıştır. Bu statüde olmayan $5 \mathrm{I}$ il merkezinin kentsel nüfus yoğunlukları ortalaması ise 83,27 kişi/ha'dır. Büyükşehir belediyesi olan, ancak merkez kent nüfus yoğunluğu diğer kentlere göre daha düşük olan iller (örn. Van, Konya, Antalya) bulunmaktadır. Bununla birlikte elde edilen değerler karşılaştırıldığında, büyükşehir belediyelerinin kentsel nüfus yoğunluklarının diğer kentlere göre daha fazla olduğu sonucu karşımıza çıkmaktadır (Şekil 8).

II merkezlerinin kentsel nüfus yoğunlukları, ArcGIS 10.3 programında Doğal Aralık Sınıflaması (Natural Breaks Classification) uygulanarak 5 kategoride gruplandırıldığında, $8 \mathrm{I}$ il merkezinden 13 'ünün (\%16) 27,77 kişi/ha - 57,53 kişi/ha aralı̆ı̆nda; 25 'inin (\%3।) 57,54 kişi/ha - 89,28 kişi/ha aralığında; 20'sinin (\%25) 89,29 kişi/ha - II3,77 kişi/ha aralığında; I2'sinin (\% I5) II3,78 kişi/ha - 156,19 kişi/ha aralığında ve II'inin (\%।3) 156,20 kişi/ ha - 194,66 kişi/ha aralığında yer aldığı tespit edilmiştir (Şekil 8).

Çalışmada aynı zamanda kentsel yerleşik alan büyüklüğü ve nüfus verilerinin, nüfus yoğunluğuna olan etkisi de incelenmiş- tir. Bu amaçla 81 il merkezine ait veriler ele alınarak korelasyon analizinin yapılması gerekmektedir. İstatistiksel olarak nüfus, nüfus yoğunluğu ve yerleşik alan büyüklüğü arasındaki ilişkinin tespit edilebilmesi için verilerin normal dağlım göstermesi gerekmektedir. Bu nedenle çalışmada SPSS programı kullanılarak kentlere ait bu üç parametreye ait verinin normal dağılıma uyum gösterip/göstermediği incelenmiştir. Ancak parametrik istatistiksel yöntemler kullanılarak analiz edilecek $8 \mathrm{I}$ kente ait verilerin normal dağılım istatistiği test edilmiş ve verilerin normal dağılım göstermediği saptanmıştır. Verilerin kendi içinde normal dağılım gösterebilmesi için kategorizasyona gidilmiştir ve söz konusu ilişki, I) "büyükşsehir statüsüne sahip olan kentler" ve 2) "büyükşehir statüsüne sahip olmayan kentler" olmak üzere iki kategoride incelenmiştir. Parametrik istatistiksel yöntemler kullanılarak analiz edilecek bu iki kategorinin normal dağılım istatistiği, çarpıklık (skewness) ve basıklık (kurtosis) değerleri açısından test edilmiştir. Bu noktada, normal dağııımın gözlenebilmesi için verilerin frekans dağıım grafiklerinin simetrik olması, bir başka ifadeyle dağıım grafiklerinin sağa veya sola çarpık ya da sivri veya basık olmaması gerekmektedir. Belirtilen iki kategoride verilerin dağılı- 


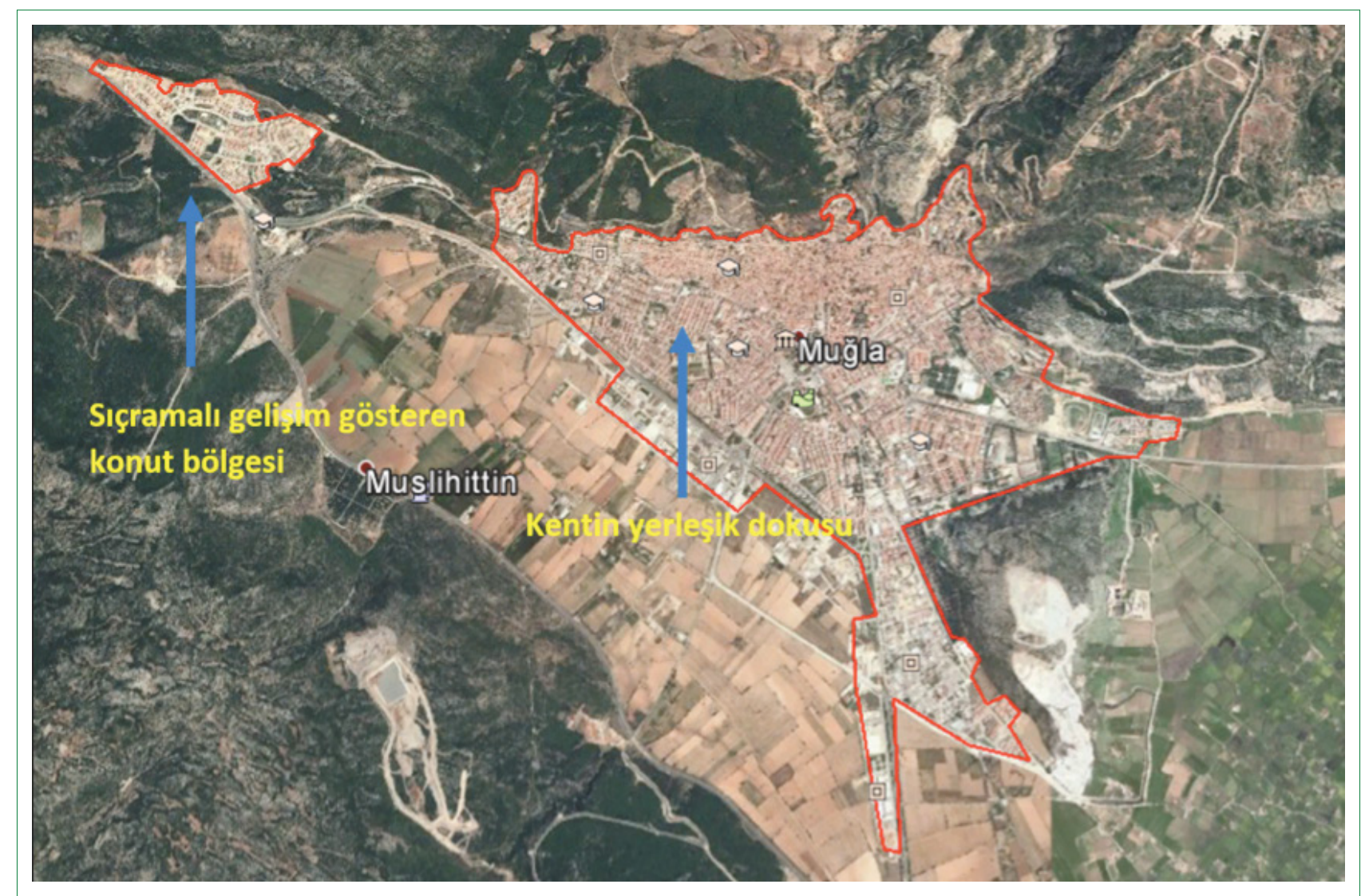

Şekil 6. Sıçramalı konut gelişimi (Muğla örneği) (Kaynak: Google Earth Pro programından yararlanarak yazarlar tarafından çizilmiştir).

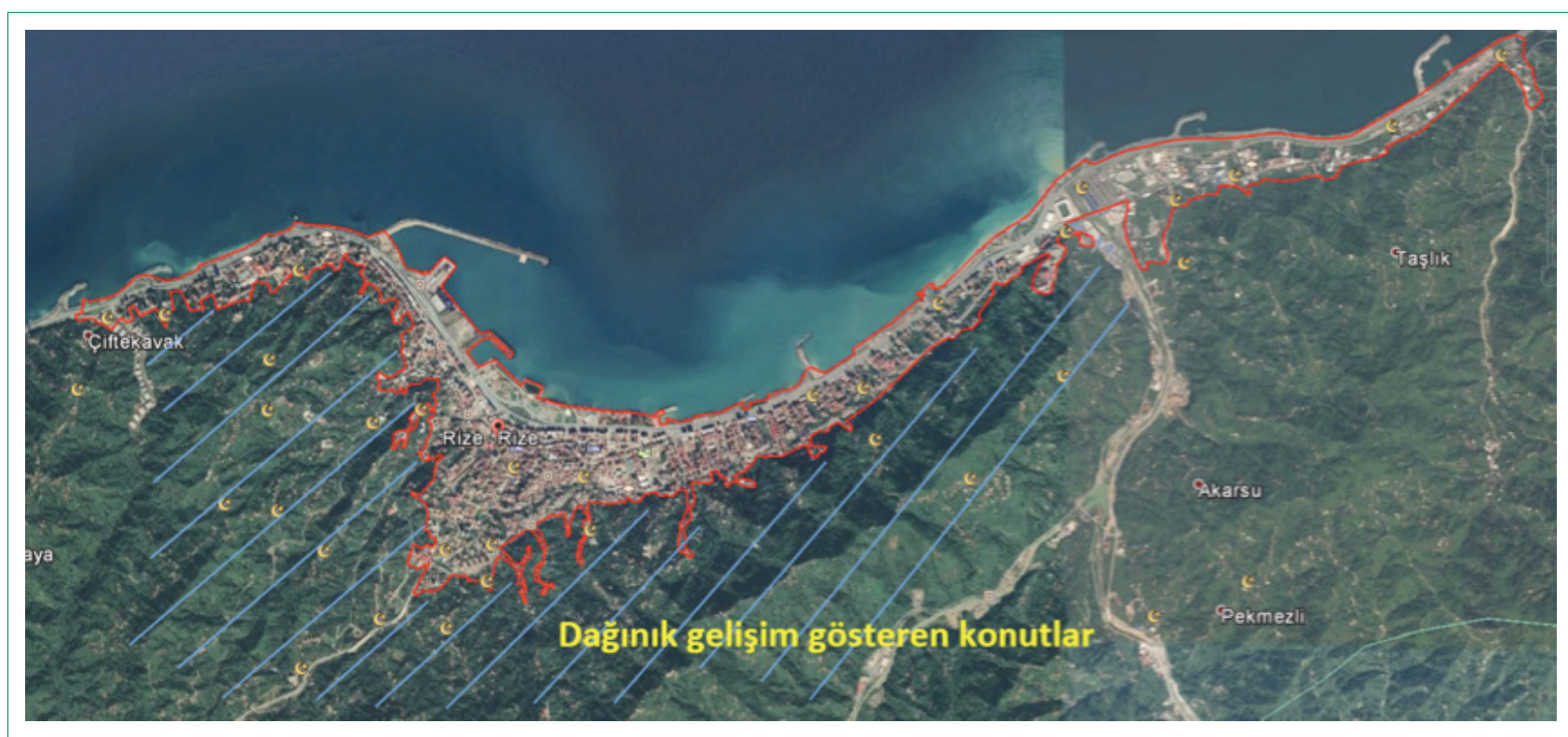

Şekil 7. Sıçramalı konut gelişimi (Muğla örneği) (Kaynak: Google Earth Pro programından yararlanarak yazarlar tarafından çizilmiştir).

mı incelendiğinde, büyükşehir belediyesi statüsünde olmayan kentlere ait verilerin normal dağıldığı, ${ }^{2}$ ancak büyükşehir sta- tüsünde bulunan kentlere ait verilerin ise normal dağılmadı̆̆ tespit edilmiştir (Tablo 4). Büyükşehir belediyesi kategorisin-

2 Bu dağıımda +2.0 ve -2.0 aralığındaki çarpıklık ve basıklık değerleri, verilen normal dağıldığını göstermektedir (George ve Mallery, 20।0). 
Tablo 2. Türkiye kentsel yerleşik alan (il merkezleri) büyüklükleri (20I5)

\begin{tabular}{|c|c|c|c|c|c|}
\hline İl adı & ha & İl adı & ha & İl adı & ha \\
\hline Adana & 16668 & Giresun & 1027 & Samsun & 3859 \\
\hline Adiyaman & 2443 & Gümüşhane & 229 & Siirt & 1132 \\
\hline Afyon & 2265 & Hakkari & 637 & Sinop & 895 \\
\hline Ağrı & 1666 & Hatay & 4708 & Sivas & 2666 \\
\hline Amasya & 708 & Isparta & 2512 & Tekirdağ & 2179 \\
\hline Ankara & 43365 & Mersin & 8563 & Tokat & 1322 \\
\hline Antalya & 16308 & İstanbul & 87145 & Trabzon & 2937 \\
\hline Artvin & 193 & İzmir & 21600 & Tunceli & 599 \\
\hline Aydın & 2010 & Kars & 1096 & Şanlıurfa & 4485 \\
\hline Balıkesir & 2542 & Kastamonu & 1446 & Uşak & 2512 \\
\hline Bilecik & 785 & Kayseri & 7017 & Van & 10722 \\
\hline Bingöl & 1083 & Kırklareli & 747 & Yozgat & 942 \\
\hline Bitlis & 880 & Kırşehir & 3048 & Zonguldak & 3162 \\
\hline Bolu & 2927 & Kocaeli & 8612 & Aksaray & 5667 \\
\hline Burdur & 2316 & Konya & 19817 & Bayburt & 543 \\
\hline Bursa & 11970 & Kütahya & 2087 & Karaman & 2301 \\
\hline Çanakkale & 1476 & Malatya & 4684 & Kırıkkale & 4995 \\
\hline Çankırı & 854 & Manisa & 1954 & Batman & 3551 \\
\hline Çorum & 3066 & K.maraş & 3991 & Şırnak & 380 \\
\hline Denizli & 6247 & Mardin & 862 & Bartın & 884 \\
\hline Diyarbakır & 5497 & Muğla & 567 & Ardahan & 448 \\
\hline Edirne & 1789 & Muş & 1173 & lğdır & 2740 \\
\hline Elazığ & 4112 & Nevşehir & 1554 & Yalova & 1800 \\
\hline Erzincan & 3442 & Niğde & 2144 & Karabük & 1420 \\
\hline Erzurum & 2824 & Ordu & 1994 & Kilis & 878 \\
\hline Eskişehir & 6437 & Rize & 712 & Osmaniye & 2966 \\
\hline Gaziantep & 8614 & Sakarya & 5213 & Düzce & 2164 \\
\hline
\end{tabular}

ha: Hektar.

de olan ve normal dağılmayan kentlere ait veriler kutu grafiği (box plot) ile incelendiğinde, İzmir uç değer, Ankara ve İstanbul ise aşırı uç değer olarak karşımıza çıkmakta ve normal dağılımın bozulmasına bu üç kente ait verinin sebep olduğu görülmektedir (Şekil 9).

Şekil 9'da görülen kutu grafiği testleri sonucunda aşırı değer veren 3 kent veri setinden çıkartılmıştır. Bu uç ve aşırı uç değerler dışarıda bırakıldığında, Tablo 5 'teki gibi çarpıklık ve basıklık değerlerine göre verilerin normal dağlım gösterdiği görülmektedir.

Normal dağılım elde edildikten sonra, büyükşehir statüsüne sahip olan ve olmayan kentlerin nüfus yoğunlukları, nüfusları ve yerleşik alan büyüklükleri arasında doğrusal bir ilişki olup olmadığını, varsa bu ilişkinin yönünü ve şiddetini belirlemek için korelasyon analizine başvurulmuştur. Tablo 6'dan izlendiği gibi, korelasyon analizi sonucu, büyükşehir statüsüne sahip olmayan kentlerde $(\mathrm{N}=5 \mathrm{I})$ yerleşik alan büyüklüğü ile nüfus arasında pozitif ve yüksek korelasyon olduğu $(r=0,698, p<0,0$ I) görülmüştür. Bu kentlerde, nüfus arttıkça kentsel yerleşik alan büyüklüğünün de arttığından söz edilebilir. Büyükşehir statüsüne sahip olmayan kentlerde $(\mathrm{N}=5 \mathrm{I})$ yerleşik alan büyüklüğü ile nüfus yoğunluğunda arasında ise negatif yönlü ve orta şiddette korelasyon olduğu $(r=-0,469, p<0,01)$ tespit edilmiştir. Bu kentlerde, yerleşik alan büyüklüğü arttıkça, nüfus yoğunluğunun azaldığı sonucuna varılmaktadır. Ancak, büyükşehir statüsüne sahip olmayan kentlerde $(\mathrm{N}=5 \mathrm{I})$ nüfus ve nüfus yoğunluğu arasında anlamlı bir ilişki tespit edilememiştir $(p<0,0$ । ve $p<0,05)$. 
Tablo 3. Türkiye kentsel (il merkezleri) nüfus yoğunlukları (20I5)

\begin{tabular}{|c|c|c|c|c|c|}
\hline İl adı & kişi/ha & İl adı & kişi/ha & İl adı & kişi/ha \\
\hline Adana & 103,04 & Giresun & 104,26 & Samsun & 165,304 \\
\hline Adiyaman & 97,7122 & Gümüşhane & $|8|, 677$ & Siirt & 128,219 \\
\hline Afyon & 96,1611 & Hakkari & 90,9906 & Sinop & 45,438 \\
\hline Ağrı & 69,8433 & Hatay & 76,6041 & Sivas & 123,437 \\
\hline Amasya & 143,804 & Isparta & 85,2293 & Tekirdağ & 86,1528 \\
\hline Ankara & 105,464 & Mersin & $|13,35|$ & Tokat & 107,961 \\
\hline Antalya & 73,4577 & İstanbul & 159,109 & Trabzon & $|09,03|$ \\
\hline Artvin & 133,876 & İzmir & 133,865 & Tunceli & 57,5309 \\
\hline Aydın & 138,043 & Kars & 74,5821 & Şanlıurfa & 193,037 \\
\hline Balıkesir & 136,535 & Kastamonu & 76,6999 & Uşak & 80,2683 \\
\hline Bilecik & 75,3669 & Kayseri & 153,103 & Van & 51,6697 \\
\hline Bingöl & 99,9695 & Kırklareli & 98,4163 & Yozgat & 86,9639 \\
\hline Bitlis & 55,6227 & Kırşehir & 41,2753 & Zonguldak & 34,179 \\
\hline Bolu & 52,5395 & Kocaeli & || $3,77 \mid$ & Aksaray & 35,7043 \\
\hline Burdur & 33,8217 & Konya & 63,1015 & Bayburt & 69,8821 \\
\hline Bursa & 162,679 & Kütahya & 113,127 & Karaman & 66,1695 \\
\hline Çanakkale & 83,0711 & Malatya & 127,228 & Kırıkkale & 38,1353 \\
\hline Çankırı & 92,6124 & Manisa & $|94,66|$ & Batman & 110,599 \\
\hline Çorum & 81,6908 & K.maraş & 151,095 & Şırnak & 166,755 \\
\hline Denizli & 97,8615 & Mardin & $|8|, 74$ & Bartın & 74,7636 \\
\hline Diyarbakır & 183,527 & Muğla & 186,70 & Ardahan & $44, \mid 45$ I \\
\hline Edirne & 88,5238 & Muş & 77,6863 & lğdır & 32,2905 \\
\hline Elazığ & 89,2889 & Nevşehir & 63,5219 & Yalova & 62,3239 \\
\hline Erzincan & 27,7734 & Niğde & 61,6395 & Karabük & 82,7866 \\
\hline Erzurum & $|27,06|$ & Ordu & 101,459 & Kilis & 106,226 \\
\hline Eskişehir & 111,399 & Rize & 156,19 & Osmaniye & 75,5182 \\
\hline Gaziantep & 185,433 & Sakarya & 98,0437 & Düzce & 70,9353 \\
\hline
\end{tabular}

ha: Hektar.

Yine Tablo 6'da görüleceği üzere, büyükşehir statüsüne sahip olan kentlerde ise ( $\mathrm{N}=27$; İstanbul, Ankara ve İzmir hariç), yerleşik alan büyüklüğü ile nüfus arasında pozitif ve yüksek korelasyon olduğu $(r=0,796, p<0,01)$ görülmüştür. Bu kentlerde, nüfus arttıkça kentsel yerleşik alan büyüklüğü artmaktadır. Büyükşehir statüsüne sahip olan kentlerde $(\mathrm{N}=27)$ yerleşik alan büyüklüğü ile nüfus yoğunluğu arasında ise negatif yönlü ve orta şiddette korelasyon olduğu $(r=0,465, p<0,05)$ tespit edilmiştir. Bu kentlerde, yerleşik alan büyüklüğü arttıkça, nüfus yoğunluğunun azaldığı sonucuna varılmaktadır. Ancak, büyükşehir statüsüne sahip olan kentlerde de $(N=27)$ nüfus ve nüfus yoğunluğu arasında anlamlı bir ilişki tespit edilememiştir $(p<0,01$ ve $p<0,05)$.

Sonuçta, büyükşehir statüsüne sahip olan ve olmayan her iki kent kategorisinde de, korelasyon analizlerine göre nüfus arttıkça yerleşik alan büyüklüğü artmakta, nüfus yoğunluğu ise azalmaktadır. Ancak nüfus ile nüfus yoğunluğu arasında her iki kent kategorisinde de bir ilişki tespit edilememiştir. İl merkezlere ait nüfus yoğunluğu ve kentsel yerleşik alan büyüklüğüne ait veriler grafik anlatımla Şekil I0'da sunulmaktadır.

\section{Tartışma}

Bu makalede, Türkiye'deki $8 \mathrm{I}$ il merkezinin kentsel brüt nüfus yoğunlukları hesaplanmış ve nüfus, yerleşik alan büyüklüğü ve nüfus yoğunluğu arasındaki ilişkiyi tespit etmeye yönelik korelasyon analizi gerçekleştirilmiştir. Böylelikle öncelikle kompakt kent ölçütlerin biri olan ve en yaygın kabul gören yüksek nüfus yoğunluğu kriteri temelinde de- 


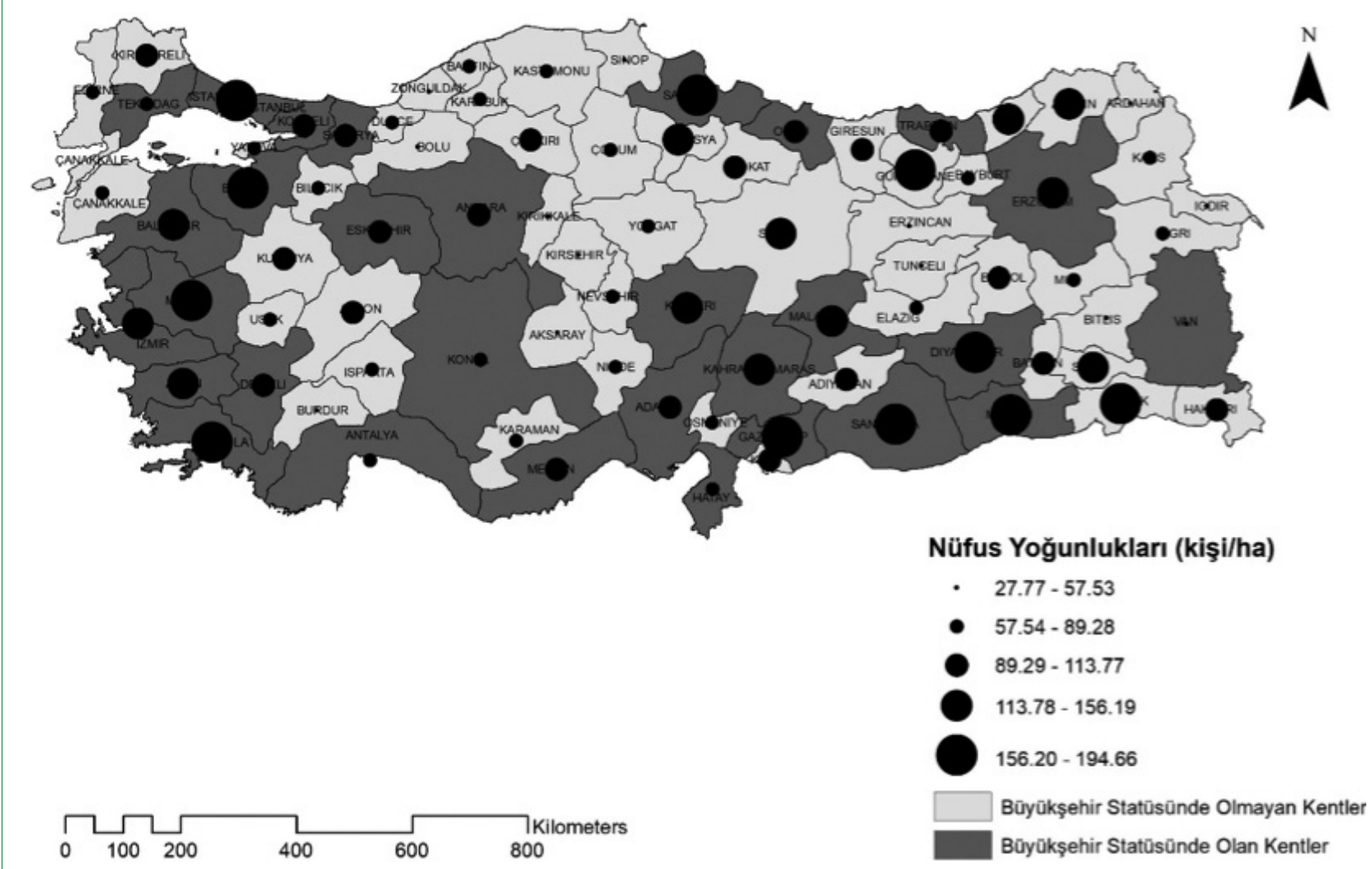

Şekil 8. Türkiye kentlerinin (il merkezleri) nüfus yoğunlukları (20I5).

Tablo 4. Uç ve aşırı uç değerlerin de yer aldığı betimleyici istatistik

\begin{tabular}{|c|c|c|c|c|c|c|c|c|c|}
\hline & \multicolumn{9}{|c|}{ Betimleyici istatistikler } \\
\hline & \multirow{2}{*}{$\frac{n}{\text { İstatistik }}$} & \multirow{2}{*}{$\frac{\text { Minimum }}{\text { İstatistik }}$} & \multirow{2}{*}{$\frac{\text { Maksimum }}{\text { İstatistik }}$} & \multirow{2}{*}{$\frac{\text { Ortalama }}{\text { İstatistik }}$} & \multirow{2}{*}{$\frac{\text { SS }}{\text { İstatistik }}$} & \multicolumn{2}{|c|}{ Çarpıklık } & \multicolumn{2}{|c|}{ Basıklık } \\
\hline & & & & & & İstatistik & SH & İstatistik & SH \\
\hline \multicolumn{10}{|c|}{ Büyükşehir statüsüne sahip olmayan kentler } \\
\hline YAB & 51 & 193 & 5667 & $|8| 1,45$ & $1216,01 \mid$ & I,07I & 0,333 & $\mathrm{I}, \mathrm{I} 44$ & 0,656 \\
\hline NF & 51 & 19777 & 392738 & $|3| 4||, 67$ & 83438,708 & 1,323 & 0,333 & 1,809 & 0,656 \\
\hline NY & 51 & 27,8 & 181,7 & 83,275 & 34,7898 & 0,734 & 0,333 & 0,611 & 0,656 \\
\hline \multicolumn{10}{|c|}{ Büyükşehir statüsüne sahip olan kentler } \\
\hline YAB & 30 & 567 & 87145 & 10779,70 & 16809,827 & 3,688 & 0,427 & 15,377 & 0,833 \\
\hline NF & 30 & 105860 & 13865524 & 1362262,50 & 2535063,331 & 4,479 & 0,427 & 21,897 & 0,833 \\
\hline NY & 30 & 51,7 & 194,7 & $|29,45|$ & 40,8361 & 0,014 & 0,427 & $-0,956$ & 0,833 \\
\hline
\end{tabular}

SS: Standart sapma; SH: Standart hata; YAB: Yerleşik alan büyüklüğü; Nf: Nüfus; NY: Nüfus yoğunluğu.

ğerlendirme yapabilmek için kentsel nüfus yoğunlukları hesaplanmış ve ülke kentlerimizin kompaktlığının ölçülebilmesine yönelik bir adım atılmıştır. Öte yandan kentsel nüfus yoğunluk ve yerleşik alan büyüklüklerine ilişkin ulusal literatüre veri kazandırılması da çalışmanın bir diğer hedefini oluşturmuştur.
Yüksek yoğunluğun dışında, kentsel kompaktlığın ölçülmesinde kullanılması gereken başka kriterler bulunmaktadır. Burton (2002)'a göre, nüfus yoğunluğunun yanı sıra yapı yoğunluğu ve alt merkez yoğunluğu da kompaktlık ölçütleri arasında yer almakta; ayrıca karma kullanım durumunun ve yoğunlaşmanın da ölçülmesi gerekmektedir. Min ve diğ. (20I2), bu ölçütleri 


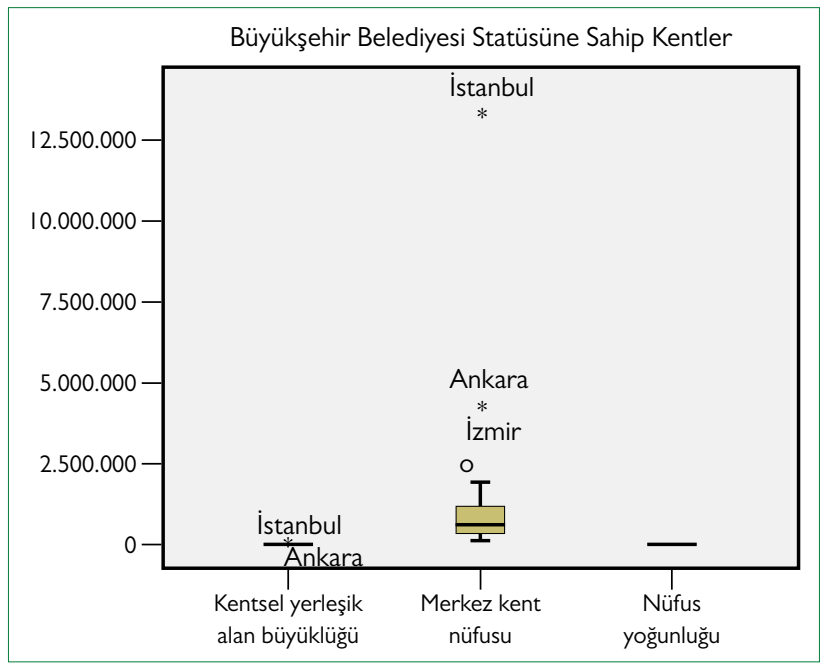

Şekil 9. Uç ve aşırı uç değerlere ait kutu grafiği.

nüfus yoğunluğu, arazi kullanımı, yol ağının özellikleri, erişilebilirlik, yerleşim yoğunluğu şeklinde sıralamaktadır. Galster ve diğ.(200I)'ne göre bu ölçütler yoğunluk, süreklilik, yoğunlaşma, kümelenme, merkezilik, çekirdeksellik, karma kullanımlar ve yakınlıktır. Tsai (2005), kompaktlığı saçaklanmadan ayıran ölçütleri boyut (nüfus), yoğunluk, eşit dağılım derecesi ve kümelenme derecesi şeklinde sıralamaktadır. Kotharkar ve diğ. (20/4) yaptıkları çalışmada kompaktlık ölçümü için yoğunluk, ulaşım ağı, erişilebilirlik, biçim ve karma kullanımIı arazi kompozisyonu kriterlerini kullanmışlardır. Görüldüğü gibi yoğunluk, kentlerin kompaktlı̆ııın ölçülmesinde ortak kabul görmekle birlikte kullanılan kriterlerden sadece birini oluşturmakta ve yoğunluk kriteri de yapı yoğunluğu ve nüfus yoğunluğu olmak üzere iki ayrı kategoride ele alınabilmektedir. Dolayısıyla belirli bir kentin kompakt olup olmadığına ilişkin kararın, her kentin ayrı ayrı ele alınıp, çoklu kriter seti üzerinden yapılacak incelemeler sonucunda verilmesi gerekmekte-
Tablo 6. Korelasyon analizi

\begin{tabular}{|c|c|c|c|}
\hline & YAB & Nf & NY \\
\hline \multicolumn{4}{|c|}{ Büyükşehir statüsüne sahip olmayan kentler } \\
\hline \multicolumn{4}{|l|}{ Alan } \\
\hline Pearson Korelasyon & 1 & $0,698 * *$ & $-0,469 * *$ \\
\hline Sig. (2-kuyruklu) & & 0,000 & 0,001 \\
\hline $\mathrm{N}$ & 51 & 51 & 51 \\
\hline \multicolumn{4}{|l|}{ Nüfus } \\
\hline Pearson Korelasyon & $0,698 * *$ & I & 0,091 \\
\hline Sig. (2-kuyruklu) & 0,000 & & 0,526 \\
\hline $\mathrm{N}$ & 51 & 51 & 51 \\
\hline \multicolumn{4}{|l|}{ Nüfus Yoğ. } \\
\hline Pearson Korelasyon & $-0,469 * *$ & 0,091 & 1 \\
\hline Sig. (2-kuyruklu) & 0,001 & 0,526 & \\
\hline $\mathrm{N}$ & 51 & 51 & 51 \\
\hline \multicolumn{4}{|c|}{ Büyükşehir statüsüne sahip olan kentler } \\
\hline \multicolumn{4}{|l|}{ Alan } \\
\hline Pearson Korelasyon & 1 & $0,796 * *$ & $-0,465^{*}$ \\
\hline Sig. (2-kuyruklu) & & 0,000 & 0,015 \\
\hline $\mathrm{N}$ & 27 & 27 & 27 \\
\hline \multicolumn{4}{|l|}{ Nüfus } \\
\hline Pearson Korelasyon & 0,796 ** & I & 0,031 \\
\hline Sig. (2-kuyruklu) & 0,000 & & 0,878 \\
\hline $\mathrm{N}$ & 27 & 27 & 27 \\
\hline \multicolumn{4}{|l|}{ Nüfus Yoğ. } \\
\hline Pearson Korelasyon & $-0,465^{*}$ & 0,031 & I \\
\hline Sig. (2-kuyruklu) & 0,015 & 0,878 & \\
\hline $\mathrm{N}$ & 27 & 27 & 27 \\
\hline
\end{tabular}

YAB: Yerleșik alan büyüklüğü; NF: Nüfus; NY: Nüfus yoğunluğu; *Korelasyon 0.05 düzeyinde anlamlıdır (2-kuyruklu); **Korelasyon 0.01 düzeyinde anlamlıdır (2-kuyruklu).

Tablo 5. Uç ve aşırı uç değerlerin veriden çıkarıldığı betimleyici istatistik

\begin{tabular}{|c|c|c|c|c|c|c|c|c|c|}
\hline & \multicolumn{9}{|c|}{ Betimleyici istatistikler } \\
\hline & \multirow{2}{*}{$\frac{n}{\text { İstatistik }}$} & \multirow{2}{*}{$\frac{\text { Minimum }}{\text { İstatistik }}$} & \multirow{2}{*}{$\frac{\text { Maksimum }}{\text { İstatistik }}$} & \multirow{2}{*}{$\frac{\text { Ortalama }}{\text { İstatistik }}$} & \multirow{2}{*}{$\frac{\text { SS }}{\text { İstatistik }}$} & \multicolumn{2}{|c|}{ Çarpıklık } & \multicolumn{2}{|c|}{ Basıklık } \\
\hline & & & & & & İstatistik & SH & İstatistik & SH \\
\hline \multicolumn{10}{|c|}{ Büyükşehir statüsüne sahip olmayan kentler } \\
\hline YAB & 51 & 193 & 5667 & 1811,45 & $1216,01 \mid$ & I,07। & 0,333 & 1,144 & 0,656 \\
\hline $\mathrm{Nf}$ & 51 & 19777 & 392738 & $|3| 4||, 67$ & 83438,708 & 1,323 & 0,333 & 1,809 & 0,656 \\
\hline NY & 51 & 27,8 & 181,7 & 83,275 & 34,7898 & 0,734 & 0,333 &, 611 & 0,656 \\
\hline \multicolumn{10}{|c|}{ Büyükşehir statüsüne sahip olan kentler } \\
\hline YAB & 27 & 567 & 19817 & 6343,74 & 5010,372 & $|, 3| 1$ & 0,448 & 1,204 & 0,872 \\
\hline $\mathrm{Nf}$ & 27 & 105860 & 1947266 & 723607,37 & 495176,200 & 0,943 & 0,448 & 0,249 & 0,872 \\
\hline NY & 27 & 51,7 & 194,7 & 129,077 & 42,4635 & 0,036 & 0,448 & $-1,068$ & 0,872 \\
\hline
\end{tabular}

SS: Standart sapma; SH: Standart hata; YAB: Yerleşik alan büyüklüğ̈; Nf: Nüfus; NY: Nüfus yoğunluğu. 


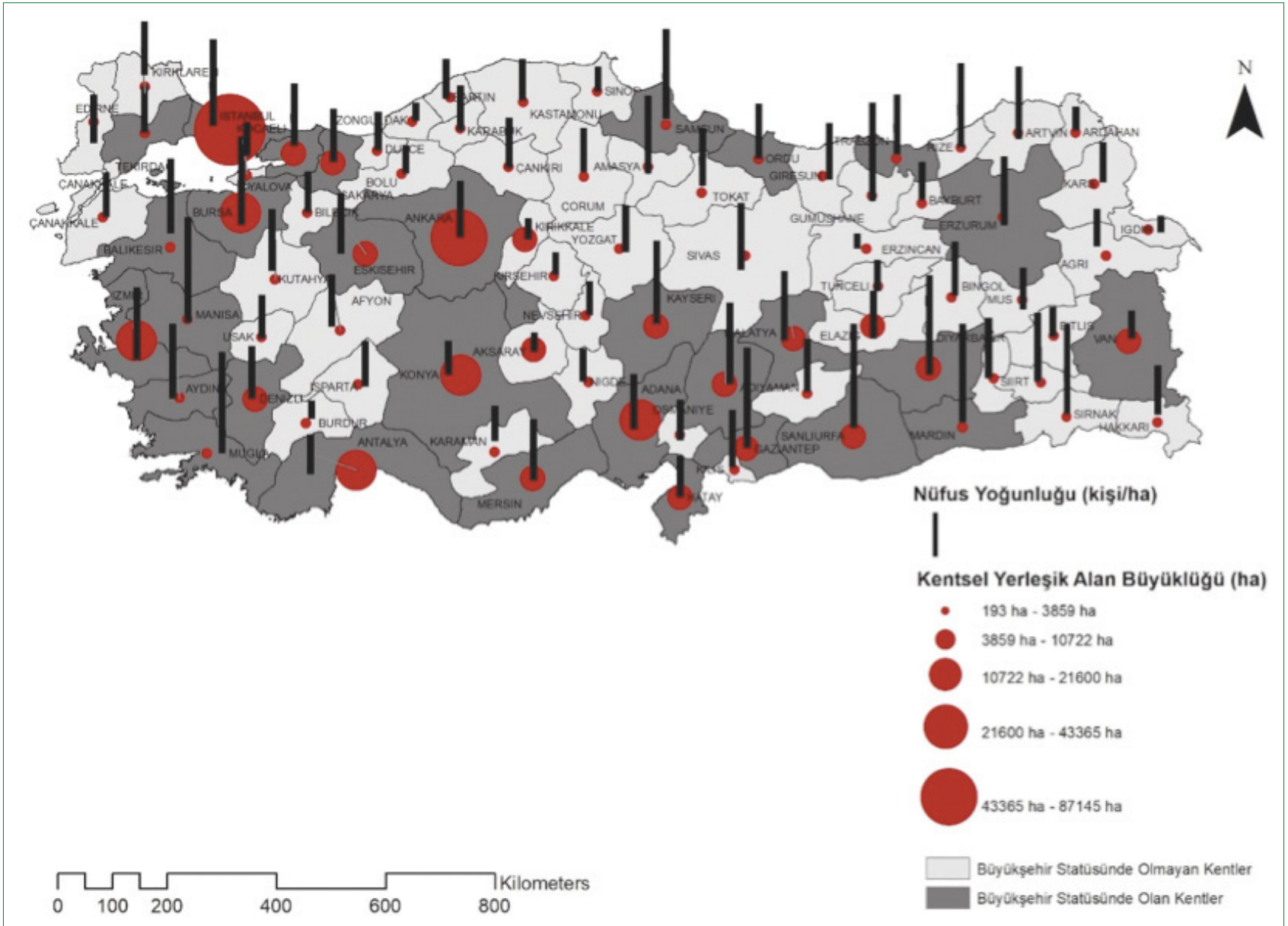

Şekil 10. Türkiye kentlerinin (il merkezleri) nüfus yoğunlukları ve kentsel yerleşik alan büyüklükleri (20I5).

dir. Bu makale kapsamında ülkemiz kentlerinin kompakt olup/ olmama durumlarını inceleyebilmek için yapılması gereken çalışmalardan biri olarak, genel kabul gören yoğunluk kriteri ele alınmış ve kentsel nüfus yoğunlukları ölçülmüştür. Daha önce belirtildiği gibi, bir kentin kompakt olarak değerlendirilebilmesinin koşullarından biri olarak yoğunluğun yüksek olması gerekmektedir. İlgili literatürde kent özelinde yapılan çalışmalarda kent merkezinden çeperlere doğru değişen yoğunluklar hesaplanmakta ve buna dayalı yüksek yoğunluk ölçütü sınanmaktadır (örn. Kotharkar ve diğ., 2014; Terzi ve Bolan, 2009). Bu makalede kent özelinde araştırma yapılmamış; ülkemizdeki 8I il merkezinin brüt nüfus yoğunluğu ölçümleri gerçekleştirilmiştir. Bu noktada, nüfus yoğunluğu açısından kompaktlık değerlendirmesi yapabilmek için yüksek yoğunluk sınıfına hangi yoğunluk kategorilerinin dahil olacağı sorusu gündeme gelmektir. Ancak böyle bir soruyu yanıtlayacak genel geçer bir standart bulunmamaktadır. Bu sorunun, farklı yoğunlukların farklı avantajlarını araştırarak ve göreceli değerlere odaklanarak deneysel araştırmalarda aşılması mümkündür (Burton, 2002). Bu noktada, hesaplanan kentsel nüfus yoğunluklarının dünya örnekleri ile kıyasından hareketle bir yoğunluk değerlendirmesine gidilmiştir. Dünya Kentsel Alan Demografisi
Tablo 7. Dünya kentleri ile Türkiye kentlerine ait brüt nüfus yoğunlukları*

\begin{tabular}{|c|c|c|c|c|}
\hline $\begin{array}{l}\text { Yoğunluk } \\
\text { (kişi/ha) }\end{array}$ & $\begin{array}{c}\text { Türkiye } \\
\text { kentleri } \\
(500.000 \text { ve } \\
\text { üstü nüfus) } \\
\text { Oran (\%) }\end{array}$ & $\begin{array}{c}\text { Türkiye } \\
\text { kentleri } \\
(500.000 \\
\text { altı nüfus) } \\
\text { Oran (\%) }\end{array}$ & $\begin{array}{c}\text { Dünya } \\
\text { kentleri } \\
(500.000 \text { ve } \\
\text { üstü nüfus) } \\
\text { Oran (\%) }\end{array}$ & $\begin{array}{c}\text { Dünya } \\
\text { kentleri } \\
(500.000 \\
\text { altı nüfus) } \\
\text { Oran (\%) }\end{array}$ \\
\hline 20-altı & 0 & 0 & 9.1 & 55.6 \\
\hline $20-40$ & 0 & 9.8 & 17.8 & 26.6 \\
\hline $40-100$ & 25 & 57.4 & 52.3 & 16.3 \\
\hline $100-200$ & 75 & 32.8 & 16.8 & 1.0 \\
\hline $200-400$ & 0 & 0 & 3.2 & 0.5 \\
\hline 400-üstü & 0 & 0 & 0.8 & 0 \\
\hline
\end{tabular}

*Tabloda Dünya kentlerine ait veriler, "Demographia World Urban Area, 2018" raporundan elde edilmiş ve yoğunluk gruplandırmaları bu raporda sunulan haliyle tabloya aktarılmıştır. Raporda kişi/kilometrekare cinsinden verilen yoğunluk değerleri tabloda kişi/hektar cinsine dönüştürülmüştür. ha: Hektar.

Raporu'nda (Demographia World Urban Area, 20/8), dünya genelinde nüfusu 500 bin ve üzeri olan kentlerin (1064 kent) ve 500 bin altında olan seçili bazı kentlerin (676 kent), kentsel 
yapılaşmış alanlarına ilişkin nüfus yoğunluğu ölçümleri yapılmıştır. Ülkemizdeki kentsel nüfus yoğunlukları ile karşılaştırma yapabilmek amacıyla, anılan raporda sunulan yoğunluk gruplandırmaları kullanılarak Tablo 7 hazırlanmıştır.

Tablo 7 incelendiğinde, 500 bin ve üstü nüfusa sahip kentler için, ülkemiz kentlerinde 40 kişi/ha ve altında hiç kentsel yerleşim olmadığı; dünya kentlerinin \%52,3'ü 40-100 kişi/ha yoğunluk aralığında yer alırken, ülkemizdeki kentlerin bu aralıkta \%25'inin yer aldığı, \%75'inin ise 100-200 kişi/ha aralığında brüt nüfus yoğunluğuna sahip olduğu görülmektedir. 500 bin nüfusun altındaki kentler için ise, ülke kentlerimizin nüfus yoğunlukları 40-200 kişi/ha aralığında çoğunlukla yer alırken, dünya kentlerinin çoğunlukla 40 kişi/ha ve altı aralığında yer aldığı görülmektedir. Sonuçta Tablo 7'de sunulan yoğunluk değerleri karşılaştırıldığında, ülkemizdeki 8 I il merkezinin yüksek kentsel nüfus yoğunluğuna sahip olduğu anlaşılmaktadır. Öte yandan nüfus, nüfus yoğunluğu ve yerleşik alan büyüklüğü arasında yapılan korelasyon analizleri sonucunda, nüfus yoğunluğunu etkileyen faktörün yerleşik alan büyüklüğü olduğu tespit edilmiştir. Kentsel yerleşik alan büyüklüğünü etkileyen her türlü faktör (yüksek katlı yapılaşma, doğal eşiklerin varlığı, yapılaşma nizamları, kentsel doluluk-boşluk oranı vb.), aynı zamanda düşük/yüksek nüfus yoğunluklarının oluşmasında rol oynamaktadır. Dolayısıyla, belirli bir kentin kompakt olup olmadığına karar vermek için bir yandan o kent üzerinde çoklu kriterlere dayalı analizlerin yapılması gerekirken diğer yandan kentsel ölçekte arazi kullanım deseni ve yapılaşma koşulları temelinde ilişkisel değerlendirmelerinin yapılması da gerekmektedir. Bu makalede, Türkiye'deki $8 \mathrm{I}$ il merkezi ele alınmış ve bu kentlerin kentsel yerleşik alanları üzerinden yoğunluk hesaplamasına gidilmiştir. Elde edilen sonuçlar, ülkemizdeki kentlerin yüksek brüt nüfus yoğunluklarına sahip olduğunu ve sadece nüfus yoğunluğu kriteri gözetildiğinde, genel olarak, kompaktlık kriterlerinden birini sağlayan bir profil çizdiğini göstermektedir.

Teşekkür: Bu makale, I0.II.20I7 tarihinde tamamlanan, 2015. KB.FEN.006 no’lu “iklim Değişikliği Azaltım ve Adaptasyon Stratejilerinin Türkiye İllerine Göre Önceliklendirilmesi” başlıklı araştırma projesi kapsamında üretilmiştir. Bu projeye destek sağlayan Dokuz Eylül Üniversitesi, Bilimsel Araştırma Projeleri Koordinasyon Birimi'ne teşekkür ederiz.

\section{KAYNAKLAR}

Aydın, M.B.S. (2015). İklim Değişikliği Sorununda Kent ve Kentsel Planlama. Yalın Yayınclik: İstanbul.

Burgess, R. (2000). The compact city debate: A global perspective. In Compact Cities: Sustainable Urban Forms for Developing Countries. (Jenks, M., Burgess, R. ed.). Spon Press, London and New York, ss.9-24.

Burton, E. (2000). The compact city: Just or just compact? A preliminary analysis. Urban Studies. Vol. 37, No. 11, 1969- 2001.

Burton, E. (2002). Measuring urban compactness in UK towns and cities. Environment and Planning B: Planning and Design, vol.29, 219-250.

Carmona, M. (2000). The regional dimension of the compact city dabate: Latin America. In Compact Cities: Sustainable Urban Forms for Developing Countries. (Jenks, M., Burgess, R. ed.). Spon Press, London and New York, ss. 53-62.

Demograpia. (2018). Demographia World Urban Areas (Built up Urban Areas or World Agglomerations). $14^{\text {th }}$ Annual Edition. http://www.demographia.com/db-worldua.pdf

Galster, G., Hanson, R., Ratcliffe, M.R., Wolman, H., Coleman, S., Freihage, J. (2001) Wrestling sprawl to the ground: Defining and measuring an elusive concept. Housing Policy Debate, 12(4), 681-717.

George, D., Mallery, M. (2010). SPSS for Windows Step by Step: A Simple Guide and Reference, 17.0 update (10a ed.) Boston: Pearson

Gordon, P., Richardson, H.W. (1997). Are compact cities a desirable planning goal? Journal of the American Planning Association, 95-106.

Jabareen, Y.R. (2006). Sustainable urban forms: Their typologies, models, and concepts. Journal of Planning Education and Research, 26, 38-52.

Kenworthy, J.R. (2006). The eco-city: ten key transport and planning dimensions for sustainable city. Environment and Urbanization, 18 (1), 67-85.

Kotharkar, R., Bahadure, P., Sarda, N. (2014). Measuring Compact Urban Form: A Case of Nagpur City, India. Sustainability, 6, 4246-4272.

Lee, J., Kurisu, K., An, K., Hanaki, K. (2015). Development of the compact city index and its application to Japanese cities. Urban Studies, 52(6), 1054-1070.

Lin J-J., Yang A-T (2006) Does the compact city paradigm foster sustainability? An empirical study in Taiwan. Environment and Planning B: Planning and Design, 33(3), 365-380.

Min C., Suxia L., Liang Y. (2012) Calculation and Analysis of Urban Compactness Using an Integrated ARCGIS Tool. In: Zhang Y. (eds) Future Wireless Networks and Information Systems. Lecture Notes in Electrical Engineering, vol 144. Springer, Berlin, Heidelberg.

Neuman, M. (2005). The compact city fallacy. Journal of Planning Education and Research. 25, 11-26.

Richardson, H.W., Bae, C.H.C, Baxamusa, M.H. (2000). Compact cities in developing countries: Assesment and implications. In Compact Cities: Sustainable Urban Forms for Developing Countries. (Jenks, M., Burgess, R. ed.). Spon Press, London and New York, ss.25-36.

Terzi, F., Bolen, F. (2009). Urban Sprawl Measurement of Istanbul. European Planning Studies, 17:10, 1559-1570.

Tosun, E.K. (2013). Sürdürülebilir kentsel gelişim sürecinde kompakt kent modelinin analizi. Yönetim ve Ekonomi. 20 (1), 31-46.

Tsai, Y. (2005). Quantifying urban Form: Compactness versus 'sprawl'. Urban Studies, 42(1), 141-161.

Van der Walls, J.F.M. (2000). The compact city and the environment: a review. Tijdschrift voor Economische en Sociale Geografie, 91 (2), 111-121. 